\title{
TINDAK TUTUR ILOKUSI PADA YOUTUBE NIHONGO MANTAPPU "JIKA AKU MENJADI MENTERI PENDIDIKAN..."
}

\author{
Fani Fatkhiyatur Rohmah*1, Elifiati Eftiftanurani ${ }^{2}$, Asep Purwo Yudi Utomo ${ }^{3}$ \\ *1,2,3 Program Studi Pendidikan Bahasa dan Sastra Indonesia, Fakultas Bahasa dan Seni, Universitas \\ Negeri Semarang \\ e-mail:*1fanifiya9@students.unnes.ac.id, ${ }^{2}$ eftifta04@students.unnes.ac.id, ${ }^{3}$ aseppyu@mail.unnes.ac.id
}

\begin{abstract}
ABSTRAK
Pada artikel ini penulis mengkaji bentuk tindak tutur ilokusi yang terdapat dalam vlog di YouTube Nihongo Mantappu milik Jerome Polin yang berjudul "JIKA AKU MENJADI MENTERI PENDIDIKAN...”. Penelitian ini bertujuan untuk menganalisis tindak tutur ilokusi menurut teori Austin yang dikembangkan menjadi lima bentuk, antara lain representatif atau asertif, komisif, direktif, ekspresif, dan deklaratif yang ada dalam video tersebut. Alasan lain yang mendasari penelitian ini adalah untuk menjelaskan maksud dan tujuan tuturan yang diucapkan Jerome Polin dalam video berbentuk opini yang membahas topik pendidikan. Jenis riset ini menggunakan pendekatan pragmatik dengan metode deskriptif kualitatif yang dilakukan dengan teknik studi dokumen, teknik simak, dan teknik catat. Hasil penelitian menyimpulkan bahwa tindak tutur ilokusi dalam vlog YouTube Nihongo Mantappu milik Jerome polin yang berjudul "JIKA AKU MENJADI MENTERI PENDIDIKAN INDONESIA ..." meliputi (1) 30 tuturan representatif atau asertif, (2) 3 tuturan komisif (3) 4 tuturan direktif, (4) 1 tuturan ekspresif, dan (5) 1 tuturan deklaratif.
\end{abstract}

Kata kunci: Tindak tutur, ilokusi, vlog, nihongo mantappu, pendidikan.

\begin{abstract}
In this article, the author examines the forms of illocutionary speech acts in the vlog on Jerome Polin's Nihongo Mantappu YouTube channel entitled "JIKA AKU MENJADI MENTERI PENDIDIKAN...". The purpose of this study was to analyze illocutionary speech acts according to Austin's theory which was developed into five namely representative or assertive, commissive, directive, expressive, and declaration in the video. Another reason that underlies this research is to explain the intent and purpose of Jerome Polin's speech in an opinion video that discusses educational topics. This type of research uses a pragmatic approach with qualitative descriptive methods carried out with document study techniques, listening techniques, and note-taking techniques. The results of the study concluded that the illocutionary speech acts in Jerome Polin's Nihongo Mantappu YouTube vlog entitled "IF I BECOME THE MINISTER OF EDUCATION OF INDONESIA..." include (1) 30 representative or assertive speeches, (2) 3 commissive speeches (3) 4 directive speeches, (4) 1 expressive speech, and (5) 1 declarative speech.
\end{abstract}

Keywords: speech act, illocutionary, vlog, nihongo mantappu, education

\section{PENDAHULUAN}

Cabang ilmu linguistik bidang kajiannya berupa bahasa dalam kegiatan berkomunikasi pada situasi tertentu adalah Pragmatik [1]. Oleh sebuah itu Pragmatik merupakan suatu kajian ilmu bahasa yang mempelajari dan topik pembahasannya adalah seputar pemakainya pada percakapan atau komunikasi yang mempunyai sebuah tujuan untuk memberikan dan menyampaikan suatu maksud tertentu yang melibatkan situasi atau konteks tertentu [2]. Unsur yang terpenting dalam aktivitas berkomunikasi adalah bahasa, dengan eksistensi bahasa maka membuat manusia bisa mengungkapkan suatu hal agar mudah dipahami dan komunikasi berjalan lancar. Tentunya setiap waktu pembicaraan manusia selalu berbeda, menyesuaikan dengan siapa ia berkomunikasi, situasi yang terjadi, latar ataupun topik yang sedang dijadikan pembicaraan dalam kegiatan komunikasi tersebut. 
Topik utama dalam kajian pragmatik salah satunya adalah tindak tutur. Tindak tutur adalah salah satu bidang kajian dari pragmatik dimana tindak tutur berperan sebagai penghubung antara tindakan yang dilakukan dengan bahasa yang digunakan [3]. Hal tersebut berarti konsep dari tindak tutur yaitu menerangkan bagaimana bahasa yang digunakan penutur diupayakan untuk mencapai tujuan sebuah tindakan serta bagaimana penutur dapat mengambil kesimpulan mengenai makna yang dimaksud hingga dapat membentuk apa yang dituturkan [4]. Teori mengenai tindak tutur diposisikan sebagai sebuah aspek dari fungsi pragmatik yang mana dikembangkan oleh J. L. Austin tahun 1962. Pada teorinya tersebut Austin memberikan penekanan yang lebih luas berkaitan dengan ketika penutur berbicara dan penutur melakukan sebuah tindakan tersebut, dalam buku yang ditulisnya berjudul "How To Do Things With World". Beliau memercayai sebuah teori yang berpusat pada tiga jenis tindak tutur yakni lokusi, ilokusi dan perlokusi [5]. Tindakan-tindakan yang disebutkan tersebut merupakan tindakan untuk menyatakan sesuatu, melakukan sesuatu, dan mempengaruhi.

Penelitian ini akan mengkaji salah satu komponen tindak tutur yaitu bentuk tindak tutur ilokusi. Tindak ilokusi merupakan tuturan yang diucapkan oleh penutur guna mencapai sesuatu yang diinginkan, dapat berbentuk seperti tindakan menyatakan, meminta maaf, berjanji, memerintah, meminta, dan lain sebagainya [6]. Tindak tutur ilokusi diistilahkan sebagai The Act Of Doing Something, yang mana cenderung tidak hanya berguna untuk menginformasikan sesuatu, namun juga untuk melakukan suatu Tindakan sejauh situasi tuturan yang disetujui sesama. [7]. Searle dengan menggunakan pendapat Austin sebagai tinjauan, mengembangkan tindak tutur ilokusi menjadi lima teori antara lain, representatif atau asertif, komisisf, direktif, ekspresif, dan deklaratif. Kelima bentuk tindak tutur ilokusi tersebut didasari dengan empat dimensi, yaitu titik atau bentuk ilokusi tindak tutur, arah hubungan atau kecocokan antar katakata dengan realita, kondisi psikologis yang diungkapkan, dan muatan proposional [2].

Seiring berkembangnya zaman, tindak tutur dijumpai dalam bermacam-macam jenis tuturan, entah ragam tuturan tulis atau lisan. Pada tuturan lisan salah satunya dapat dijumpai dalam media elektronik. Saat ini media elektronik yang memiliki banyak pengakses adalah internet, dalam dunia internet terdapat sosial media yang beragam jenisnya. Sosial media yang paling sering diakses dan popular di masyarakat sekarang adalah YouTube [8]. Hal ini dikarenakan pengguna tidak hanya dapat melihat berbagai macam video secara gratis di YouTube namun juga dapat membuat saluran pribadi dan mengunggah video kreasinya sendiri [9]. Di era milenial ini, vlog (video blog) yang mana merupakan istilah video-video diri sendiri yang diunggah di YouTube menjai pilihan anak muda untuk menyalurkan segala ide kreatifnya. Selain menjadi sarana hiburan dan kreativitas, YouTube juga memberikan dampak positif lainnya berupa pengetahuan dan wawasan untuk penonton. Fasilitas yang diberikan Youtube didukung dengan selera pengguna media elektronik yang mengharapkan media tidak hanya satu arah seperti televisi, namun juga dapat memberikan privilege pengguna untuk memberikan kritik dan sarannya secara langsung.

Salah satu YouTuber yang paling menginspirasi kaum milenial saat ini adalah Jerome Polin, penggunaan bahasa dalam vlog-vlog pada kanal YouTubenya sangat menarik untuk dikaji. Jerome merupakan seorang mahasiswa yang sedang menjalankan pendidikan sarjana jurusan matematika terapan di Waseda University, Jepang, maka kontennya kebanyakan tentang dunia pendidikan dimulai dari video opini, battle matematika, tips dan trik mengerjakan soal matematika, kuis ilmu pengetahuan, dan lain-lain. Kanal YouTube yang diberi nama Nihongo Mantappu itu kini kurang lebih telah memiliki lebih dari tujuh juta pelanggan. Salah satu kontennya yang menarik untuk kami teliti yaitu video opini dari Jerome yang membahas tentang dunia pendidikan di Indonesia. Pada video yang berdurasi kurang lebih 10 menit tersebut Jerome membicarakan tentang kritik dan saran mengenai keadaan pendidikan di Indonesia saat ini dan harapaannya untuk masa yang akan datang, didalamnya terkandung informasi, opini, dan argumen yang dikemas dengan bahasa yang komunikatif bagi para penontonnya. Alasan penulis memilih video tersebut sebagai objek kajian dalam penelitian ini karena video tersebut berbau tentang pendidikan yang tentunya banyak sekali manfaat yang bisa didapat mengingat penulis 
adalah calon pendidik, video opini tersebut disampaikan dengan baik oleh Jerome dari segi pemilihan kata dan tuturannya, terdapat banyak tuturan yang merupakan bentuk tindak tutur ilokusi, dan dikarenakan belum penelitian terdahulu yang menganalisis tindak tutur dalam video di kanal YouTube Nihongo Mantappu.

Terdapat beberapa penelitian terdahulu mengenai tindak tutur yang ditinjau penulis sebagai rujukan dalam melakukan penelitian ini, antara lain Neni dan Asep [10] yang mengkaji tindak tutur dalam video podcast Deddy corbuzier bersama Najwa Shihab, Hardiyanti, $d k k$. [11] yang mengkaji tindak tutur guru pada proses pembelajaran bahasa Indonesia di tingkat SMP, Isma Savanty [12] yang menganalisis tindak tutur ilokusi dalam wacana pembaca menulis pada surat kabar Jawa Pos, dan Veranita Ragil Sagita dan Teguh Setiawan [2] yang menganalisis bentuk dan jenis tindak tutur ilokusi Ridwan Kamil dalam Talkshow Insight di CNN Indonesia. Dari beberapa penelitian terdahulu tersebut, disimpulkan bahwa ada perbedaan dan persamaan dengan penelitian yang dilakukan penulis. Persamaannya dilihat pada focus penelitian yang mana sama-sama menitikberatkan pada tindak tutur berjenis ilokusi. Teori yang digunakan peneliti pun sama yaitu gagasan dari Seatle yang mengembangkan tindak ilokusi menjadi lima bentuk, antara lain representatif atau asertif, direktif, ekspresif, komisif, dan deklaratif. Perbedaan yang terlihat, pada penelitian terdahulu tampak objek yang dikaji mulai dari tuturan dalam wacana, proses pembelajaran, acara televisi, dan video podcast pada media sosial YouTube. Perbedaan antara penelitian terdahulu dengan penelitian saat ini adalah objek kajian yaitu tuturan dalam video pada kanal YouTube Jerome yang belum pernah dianalisis sebelumnya.

Berdasarkan teori dan permasalahan yang telah dijelaskan tersebut, tujuan penelitian ini adalah untuk menganalisis tindak tutur ilokusi menurut teori Austin yang dikembangkan menjadi lima yaitu representatif atau asertif, komisif, direktif, ekspresif, dan deklarasi dalam video opini pada kanal YouTube Nihongo Mantappu. Batasan dari penelitian ini adalah apa saja tuturan yang menunjukkan tindak ilokusi (representatif atau asertif, komisif, direktif, ekspresif, dan deklarasi) dan apa maksud dan tujuan tuturan tersebut diucapkan. Dengan menjadikan tujuan penelitian sebagai acuan, maka penulis memutuskan penelitian ini dengan judul TINDAK TUTUR ILOKUSI PADA YOUTUBE NIHONGO MANTAPPU "JIKA AKU MENJADI MENTERI PENDIDIKAN...". Sebagai penulis, kita mengharapkan agar penelitian ini dapat bermanfaat dan menambah wawasan masyarakat luas mengenai ilmu tindak tutur ilokusi. Dengan dilakukannya penelitian ini semoga dapat memberikan perkembangan teoriteori komunikasi khususnya dalam bidang pragmatik yang mempelajari tuturan. Melihat hasil penelitian ini, diharapkan peneliti dan pembaca dapat memahami macam-macam jenis tindak tutur khususnya tindak tutur ilokusi yang terbagi menjadi lima komponen. Dengan menguasai penerapan tindak tutur ilokusi, maka pembaca diharapkan memahami bahwa sebuah tuturan terdapat suatu fungsi selain untuk mengatakan atau menginformasikan sesuatu, namun juga dipergunakan untuk melakukan sesuatu. Khususnya pada video opini yang menjadi objek kajian ini, tuturan-tuturan yang diucapkan pun bermaksud untuk mendorong lawan tutur agar memberikan respon dengan melakukan suatu tindakan.

\section{METODOLOGI PENELITIAN}

Dalam penelitian artikel ini, peneliti menggunakan kajian pendekatan pragmatik, dengan penyelidikan terkait bagaimana peneliti sebagai pendengar menyimpulkan hal-hal yang dituturkan penutur agar dapat menangkap sebuah interpretasi makna yang dimaksudkan oleh penutur Penelitian ini merupakan kajian pragmatik yang menggunakan metode deskriptif kuantitatif dalam analisis datanya dan merupakan kajian pragmatik dengan metode deskriptif kualitatif dalam telaah datanya. Sumber data dalam analisis kualitatif adalah kata-kata ataupun juga aksi tindakan, selain itu juga dapat berupa data yang berasal dari dokumen atau sebagainya [13].

TINDAK TUTUR ILOKUSI PADA YOUTUBE NIHONGO MANTAPPU 'JIKA AKU MENJADI MENTERI

PENDIDIKAN...' (FANI FATKHIYATUR ROHMAH ${ }^{1}$, ELIFIATI EFTIFTANURANI ${ }^{2}$, ASEP PURWO YUDI $\mathrm{UTOMO}^{3}$ ) 
Analisis dalam artikel ini berfokus pada analisis tindak tutur ilokusi, objek yang akan dianalisis menggunakan sumber data yang berasal dari video dalam kanal YouTube Nihongo Mantappu milik Jerome polin yang dipublikasikan pada tanggal 2 Januari 2019 berjudul "JIKA AKU MENJADI MENTERI PENDIDIKAN INDONESIA...". Data yang ada pada penelitian ini adalah transkrip tuturan yang berupa kalimat atau paragraf yang menunjukkan adanya tindak tutur ilokusi dalam video tersebut. Pengumpulan data dilakukan dengan menggunakan metode kualitatif teknik studi dokumen, dengan prosedur ini kemudian dihasilkan data deksriptif. Teknik lainnya yang diperlukan adalah teknik catat, hal tersebut diperlukan untuk mempermudah dalam pengklasifikasian data, mengingat teknik merupakan kegiatan mengambil hal-hal yang dianggap penting yang berhubungan dengan data. Langkah pertama untuk mengumpulkan data penelitian akan dilakukan teknik yang bertolak belakang dengan teknikteknik yang telah disebutkan sebelumnya, yaitu menonton dan menyimak video yang akan dianalisis.

Tahap selanjutnya menggunakan teknik lanjutan dari teknik simak, yaitu teknik catat. Peneliti mencatat semua tuturan yang ada dalam video, baik tuturan lisan maupun tulisan dan dilanjutkan dengan pengelompokan data-data yang termasuk dalam beberapa golongan tindak tutur ilokusi untuk dapat diolah dan diidentifikasi lebih lanjut dalam tahap analisis. Kemudian, peneliti menganalisis tuturan tersebut apakah tuturan tersebut termasuk tindak tutur ilokusi jenis asertif, direktif, deklaratif, komisif, atau ekspresif. Penjelasan deskriptif akan dipaparkan setelah pengelompokan data setiap golongan tindak tutur ilokusi yang sudah dikelompokkan sebelumnya. Instrumen dalam penelitian ini menggunakan peneliti sendiri sebagai sarana penelitian untuk mengumpulkan data, hal tersebut karena peneliti berperan sebagai perencana, pengumpul data, penganalisis data, penafsiran data, menyimpulkan data dan juga sebagai seseorang yang melaporkan hasil analisisnya. Hal-hal diatas terikat dengan hasil dan pembahasan peneliti dalam pengklasifikasian tindak tutur ilokusi yang tepat.

\section{Hasil Penelitian}

\section{HASIL DAN PEMBAHASAN}

Berdasarkan penelitian yang telah dilakukan, peneliti menunjukkan adanya jenis tindak tutur ilokusi dalam video di kanal YouTube Nihongo Mantappu milik Jerome Polin yang berjudul "JIKA AKU MENJADI MENTERI PENDIDIKAN INDONESIA..." keseluruhan berjumlah 39 tuturan yang meliputi: (1) 30 tuturan representatif atau asertif, (2) 3 tuturan direktif, (3) 4 tuturan komisif, (4) 1 tuturan ekspresif, dan (5) 1 tuturan deklaratif. Hal tersebut diperoleh berdasarkan penyelesaian data yang telah dilakukan dalam proses analisis dengan teknik menyimak video tersebut kemudian mencatat tuturan berdasarkan bentuk ilokusi. Untuk memperjelas jumlah bentuk tindak tutur beserta fungsi relasinya di atas dapat dilihat di tabel berikut:

Tabel 1. Jumlah fungsi dari bentuk tindak tutur ilokusi

\begin{tabular}{ccc}
\hline $\begin{array}{c}\text { Bentuk Tindak Tutur } \\
\text { Ilokusi }\end{array}$ & $\begin{array}{c}\text { Fungsi Relasi Tindak } \\
\text { Tutur Ilokusi }\end{array}$ & Jumlah \\
\hline Representatif atau Asertif & Menyatakan & 11 \\
& Memberitakan & 8 \\
& Mengemukakan pendapat & 3 \\
& Mengeluh & 3 \\
& Menyimpulkan & 3 \\
& Mengklain & 1 \\
& Melaporkan & 1 \\
\hline
\end{tabular}




\begin{tabular}{ccc}
\hline Komisif & Menjanjikan & 3 \\
Direktif & Permintaan & 2 \\
& Penawaran & 1 \\
& Nasehat & 1 \\
Ekspresif & Tidak suka & 1 \\
Deklaratif & Mempengaruhi & 1 \\
& Jumlah & 39 \\
\hline
\end{tabular}

\section{Pembahasan}

Berikut adalah beberapa contoh paparan dari hasil analisis data yang ditemukan sebagai pembahasan terhadap topik penelitian yaitu jenis tindak tutur dalam video di kanal YouTube Nihongo Mantappu milik Jerome Polin yang berjudul "JIKA AKU MENJADI MENTERI PENDIDIKAN INDONESIA..." dan juga fungsi realisasi tindak tuturnya.

\section{Representatif atau asertif}

Tindak tutur yang mendorong penutur menuju realita proporsi yang ditunjukkan hingga membawanya pada sebuah nilai kebenaran [14]. Ketika mengungkapkan bentuk tindak tutur ini, penutur mewakili dunia yang dipercayai apa adanya maka akan mengakibatkan kata-kata yang dituturkan cocok dengan dunianya [15]. Relasi fungsinya antara lain seperti kata-kata menyatakan, memberitakan, melaporkan, mengklaim, dan mengeluh.

(1) "Mungkin judul video ini (Jika Aku Menjadi Menteri Pendidikan Indonesia) berlebihan, karena pasti kalau menjadi menteri akan lebih banyak lagi hal-hal yang harus dilakukan. Tetapi ini opiniku pribadi menurut pengalamanku dan orang-orang disekitarku yang mungkin nggak mutlak bener, jadi kalau kalian punya opini lain silahkan komentar dibawah."

Konteks: Tuturan diucapkan oleh Jerome terkait maksud isi videonya tersebut adalah pendapat pribadi dan masyarakat yang mungkin tidak mutlak benar.

Tuturan yang diucapkan oleh Jerome tersebut termasuk salah tuturan jenis asertif mengklaim, karena dalam tuturan tersebut yang ada pada pembukaan video Jerome berusaha memastikan penonton bahwa video ini adalah opini dan belum mutlak kebenarannya. Bisa saja video ini benar, namun bisa saja ada beberapa bagian yang tidak sesuai. Jadi, Jerome mengatakan tuturan ini pada penonton agar tidak ada kesalahpahaman sebelum mereka akan melihat isi video tersebut. Karena yang namanya opini pasti masih memiliki dua sisi yang memang belum seluruhnya benar, tergantung dari pandangan dan pengetahuan masing-masing.

(2) "Jadi beberapa waktu lalu aku scrolling explore Instagramku dan ada satu foto yang menarik perhatianku. Itu adalah foto orang menang lomba game di Indonesia, dan itu hadiahnya besar banget."

Konteks: Tuturan diucapkan oleh Jerome yang melihat hadiah perlombaan game sangat besar. Tuturan yang diucapkan oleh Jerome tersebut termasuk salah tuturan jenis asertif melaporkan, karena dalam tuturan tersebut Jerome mengatakan pada penonton bahwa kemarin dia melihat foto di Intagram, foto itu menampilkan hadiah perlombaan game yang jumlahnya sangat besar. Jerome menceritakan apa yang telah dia lihat sebelumnya pada penonton agar mereka juga tahu, dan tuturan ini bermaksud sebagai awalan yang akan menyambungkan topik pembahasan selanjutnya.

(3) "Pas SMA aku tuh sering banget ikut lomba, bidangku matematika. Dan aku nggak cuma ikut lomba Matematika, tapi aku juga ikut lomba-lomba lain misalnya teknik industri, teknik kimia, farmasi, dan lain-lain." 
Konteks: Tuturan diucapkan oleh Jerome yang menyatakan dirinya saat SMA sering mengikuti perlombaan.

Tuturan yang diucapkan oleh Jerome tersebut termasuk salah tuturan jenis asertif menyatakan, Jerome menuturkan pada penonton untuk memberitahukan bahwa dia dulu saat sekolah sering mengikuti perlombaan di bidang akademik.

(4) "Menurut pribadiku yang pernah ikut lomba-lomba pelajaran, hadiahnya tuh nggak pernah lebih dari 100 juta."

Konteks: Tuturan diucapkan oleh Jerome yang melaporkan bahwa hadiah lomba pelajaran tidak sebesar lomba gaming."

Tuturan yang diucapkan oleh Jerome tersebut termasuk salah tuturan jenis asertif mengeluh, pada tuturan ini Jerome mengatakan pada penonton jika hadiah lomba pelajaran tidak pernah ada yang lebih dari 100 juta, disini dia membandingkan dengan hadiah lomba gaming yang dilihat sebelumnya. Terdapat unsur mengeluh pada tuturan ini yang bermaksud mengapa lomba pelajaran yang bermanfaat justru hadiahnya dikalahkan jauh dari lomba gaming yang notabenenya hanya kesenangan semata.

(5) "Di sini aku melihat kalau misalnya ternyata lomba gaming sekarang ini lebih diminati daripada lomba pelajaran, kenapa seperti itu? karena kita sebagai murid atau mahasiswa kan belum punya uang banyak, dan ketika lomba lalu mendapat uang yang banyak pasti kita akan mengejar itu."

Konteks: Tuturan diucapkan oleh Jerome merupakan bentuk opini bahwa lomba gaming lebih banyak diminati karena hadiahnya yang besar.

Tuturan yang diucapkan oleh Jerome tersebut termasuk salah tuturan jenis asertif mengemukakan pendapat, melihat peristiwa saat ini dimana perlombaan gaming lebih banyak diminati ketimbang perlombaan pelajaran, Jerome memberikan pendapatnya bahwa anak-anak lebih minat ke gaming dikarenakan tergiur dengan hadiahnya yang jauh lebih banyak daripada lomba pelajaran. Pendapat ini sangat relevan karena didukung dengan alasan anak-anak yang belum bekerja dan tidak memiliki banyak uang pastinya akan senang jika mendapat uang yang banyak.=

(6) "Dengan pola pikir yang sama, ketika minatnya banyak, maka banyak murid itu bersaing dan akhirnya mereka belajar dengan sungguh-sungguh, ketika itu maka skill mereka akan sangat tinggi dan bahkan mereka juga bisa menemukan formula-formula baru juga mungkin menemukan hal-hal baru gitu, kayak misalnya mereka bisa nemuin trik menjawab soal yang harusnya 10 menit bisa dikerjakan dalam waktu 2 menit."

Konteks: Tuturan diucapkan oleh Jerome mengenai minat yang tinggi akan memunculkan daya saing.

Tuturan yang diucapkan oleh Jerome tersebut termasuk salah tuturan jenis asertif menyimpulkan, Jerome menyampaikan tuturan pada penonton berupa kesimpulannya terhadap fenomena banyaknya peminat lomba gaming daripada lomba pelajaran, dia menyimpulkan jika suatu perlombaan banyak peminatnya maka akan tinggi pula daya saingnya, hal ini akan membuat partisipannya bersungguh-sungguh untuk bisa mengikuti perlombaan sehingga kemampuan mereka pun tidak main-main.

(7) "Nah, yang ketiga adalah gaji guru di Indonesia termasuk rendah."

Konteks : Tuturan diucapkan oleh Jerome Polin yang memberikan informasi bahwa gaji guru di Indonesia rendah.

Tuturan yang diucapkan oleh Jerome tersebut termasuk salah tuturan jenis asertif memberitakan, karena dalam tuturan tersebut memberikan dorongan ke arah kebenaran proporsi yang ditunjukkan oleh Jerome dengan memberitakan sebuah informasi mengenai gaji guru di Indonesia. 


\section{Komisif}

Bentuk tindak tutur yang mendorong penuturnya untuk melakukan beberapa tindakan dimasa depan. Tindak tutur ini menjelaskan tujuan dari penutur yang akan melakukan suatu hal seperti janji, sumpah, tawaran, ancaman, dan penolakan [16].

(1) "Kalau aku bisa berkontribusi untuk pendidikan, aku akan memperbesar gengsi dan juga memperbesar minat siswa untuk ikut lomba pelajaran, sehingga banyak orang ikut lomba dan akhirnya banyak orang yang mau belajar, maka akhirnya kemampuan siswa Indonesia meningkat dan Indonesia tidak akan kalah dari negara lain."

Konteks: Tuturan diucapkan oleh Jerome mengenai tindakannya jika berkontribusi di pendidikan Indonesia

Tuturan yang diucapkan oleh Jerome tersebut termasuk salah tuturan jenis komisif janji, Jerome mengungkapkan ke penonton jika dia dimasadepan nanti berkesempatan untuk berkontribusi di dunia Pendidikan dia berjanji akan memperbesar gengsi dan minat siswa untuk mengikutiperlombaan pelajaran, agar tercipta kemampuan siswa yang tinggi dan tak kalah dari negara lain.

\section{Direktif}

Bentuk tindak tutur yang menyebabkan mitra tutur menjalankan suatu tindakan atas tuturan yang diucapkan penutur. Pada jenis tindak tutur ini, penutur memiliki harapan agar mitra tutur melakukan tindakan sesuai dengan arahannya yang bertujuan untuk menjadikan perubahan dunia di masa depan [17].

(1) "Jumlah hadiah uang yang besar ini membuat orang-orang semakin minat untuk ikut lomba itu, ketika minat untuk ikut perlombaan itu tinggi, maka muncullah persaingan disitu, ketika ada persaingan maka orang-orang ini harus prepare harus persiapan dengan baik dan serius dalam latihan, hingga levelnya tinggi semua dan akhirnya skillskill mereka terasah, bahkan mungkin mereka menemukan trik-trik baru dalam game, informasi baru yang belum ada sebelumnya."

Konteks: Tuturan diucapkan oleh Jerome yang menghubungkan antara hadiah yang besar dengan minat dan daya saing anak dalam perlombaan.

Tuturan yang diucapkan oleh Jerome tersebut termasuk salah tuturan jenis direktif permintaan, dalam tuturan itu Jerome tampak menghubungkan bahwa hadiah yang besar akan berdampak terhadap minat dan daya saing anak dalam suatu perlombaan. Disini dia secara tidak langsung meminta agar pemerintah lebih memperhatikan hadiah dan apresiasinya untuk perlombaan pelajaran agar generasi-generasi emas ini semakin semangat untuk mengasah dan menunjukkan kemampuannya.

(2) "Nah jadinya inti disini adalah persaingan itu dan juga minat. Setelah itu aku jadi mikir gimana kalau misalnya olimpiade pelajaran-pelajaran bisa memberikan hadiah sebesar itu, karena dalam bayanganku murid-murid pasti minat banget untuk ikut. "

Konteks: Tuturan diucapkan oleh Jerome yang membayangkan bagaimana jika hadiah perlombaan sekolah sebesar perlombaan gaming.

Tuturan yang diucapkan oleh Jerome tersebut termasuk salah tuturan jenis direktif penawaran, Jerome membayangkan apabila pemerintah memberikan hadiah perlombaan pelajaran sama besar dengan lomba gaming, mungkin anak-anak akan semangat untuk mengikuti perlombaan pelajaran, dan menyebabkan tingginya minat dan daya saing.

(3) "Dukungan dari pihak sekolah dan pemerintah sangat dibutuhkan para siswa. Sehingga menurutku hal ini perlu diperhatikan lebih serius dan ditingkatkan, aku berharap sekolah dan pemerintah bisa lebih peka dan mendukung penuh terhadap keinginan siswa untuk mengikuti perlombaan." 
Konteks: Tuturan diucapkan oleh Jerome yang berharap pada pihak sekolah dan pemerintah agar selalu mendukung anak dalam perlombaan.

Tuturan yang diucapkan oleh Jerome tersebut termasuk salah tuturan jenis direktif nasehat, Jerome mengungkapkan harapannya sekaligus nasehat untuk pemerintah agar lebih peka dan mendukung dengan penuh anak-anak yang berkeinginan mengikuti perlombaan pelajaran.

(4) "Jangan lupa like dan juga subscribe dan juga share video ini ke teman teman kalian."

Konteks : Tuturan disampaikan oleh Jerome kepada penonton sebagai mitra tuturnya untuk tidak lupa menyukai video youtubnya dan juga menyebarkan video tersebut kepada temanteman mitra tutur Jerome.

Dalam tuturan tersebut Jerome meminta mitra tuturnya yaitu penonton video untuk jangan sampai lupa menyukai dan menyebarluaskan videonya tersebut kepada orang lain. Tuturan tersebut termasuk pada bentuk tindak tutur ilokusi yang berjenis direktif meminta, dimana seperti yang disebutkan sebelumnya Jerome meminta penonton sebagai mitra tuturnya untuk menyukai dan menyebarluaskan videonya tersebut.

\section{Ekspresif}

Bentuk tindak tutur ini, penutur akan mengungkapkan suatu tuturan berupa pernyataan psikologis yang memiliki relasi fungsi berwujud rasa kegembiran, suka atau tidak suka pada suatu hal, atau kesedihan [18].

(1) "capek, aku udah belajar terus di sekolah, ngapain aku belajar lagi sendiri."

Konteks : Tuturan disampaikan oleh Jerome, namun bukan untuk mengekspresikan perasaan dirinya. Melainkan mengekspresikan bagaimana keadaan siswa jika belajar sendiri setelah seharian belajar di sekolah.

Dalam tuturan tersebut Jerome sebagai penutur menempatkan dirinya sebagai seorang siswa yang menunjukkan ketidaksukaannya terhadap sebuah keadaan yang terjadi apabila seorang siswa lelah harus belajar lagi sendiri padahal sudah belajar seharian di seko

\section{Deklaratif}

Bentuk tindak tutur yang memberikan pengaruh atau perubahan suatu peristiwa yang terjadi saat itu. Biasanya diutarakan oleh pihak tertentu yang mewakili suatu komunitas.Dalam mengungkapkan tuturannya, penutur akan memberikan suatu perubahan [19].

(1) "Nah, tapi ngga begitu doang, soalnya nanti murid-murid akan main kan, jadi harus ditanamkan kesadaran terlebih dahulu, mereka harus ngapain.

Konteks : Tuturan diucapkan oleh Jerome Polin untuk memberikan pengaruh pada mitra tutur untuk melakukan tindakan yang harus dilakukan sesuai keadaan saat ini.

Tuturan yang disampaikan oleh Jerome tersebut merupakan tuturan berjenis deklaratif, dimana Jerome memberikan mitra tutur pengaruh untuk hal yang harus dilakukan pada keadaannya saat itu, hal yang akan lebih baik dilakukan pada saat itu adalah dengan menanamkan kesadaran terlebih dahulu. Karena suatu hal Jerome tidak dapat langsung mempengaruhi murid untuk melakukan sesuatu, namun yang pertama harus dilakukan adalah menumbuhkan kesadaran diri murid-murid terlebih dahulu.

\section{SIMPULAN}

Berdasarkan analisis yang dilakukan, penulis menemukan tuturan-tuturan yang disampaikan Jerome Polin dalam video YouTube Nihongo Mantappu yang berjudul "Jika Aku Menjadi Menteri Pendidikan...", Dimana termasuk dalam bentuk tindak tutur iIokusi. Adapun hasil data yang ditunjukkan berdasarkan analisis adalah (1) Representatif atau asertif berjumlah 30 tuturan yang memiliki fungsi mengklaim 1 tuturan, fungsi melaporkan 1 tuturan, fungsi 
menyatakan 11 tuturan, fungsi mengeluh 3 tuturan, fungsi mengemukakan 3 tuturan, fungsi menyimpulkan 3 tuturan, dan fungsi memberitakan sebanyak 8 tuturan. (2) Komisif sebanyak 3 tuturan, yang ketiganya berupa tindak tutur ilokusi komisif yang memiliki fungsi menjanjikan suatu hal. (3) Direktif sebanyak 4 tuturan yang masing-masing memiliki fungsi direktif permintaan, penawaran, nasehat, dan meminta. (4) Ekspresif sebanyak 1 tuturan yang berfungsi menunjukkan ekspresi tidak suka. Dan (5) Deklaratif sebanyak 1 tuturan berupa tuturan yang memiliki fungsi mempengaruhi. Dari hasil tersebut, bentuk tindak tutur ilokusi yang paling banyak ditemukan adalah bentuk representatif atau asertif, hal tersebut menunjukkan bahwa tuturan yang disampaikan oleh Jerome sebagai penutur sesuai dengan tema dan judul video tersebut yang edukatif dan bersumber dari opini penutur, yang mana didominasi dengan tuturan menyatakan, mengeluh, mengemukakan pendapat, memberitakan, dan menyimpulkan. Dengan adanya analisis bentuk tuturan ilokusi dalam artikel ini penulis berharap para pembaca mendapatkan manfaaat dan pengetahuan terkait penggunaan tindak tutur ilokusi dan fungsi yang sebenarnya sangat dekat dengan aktivitas tutur masyarakat.

\section{REFERENCES}

[1] S. Agus, "Analisis Tindak Tutur Bahasa Jawa di Pasar Sampang Kecamatan Sampang Kabupaten Cilacap," J. Progr. Stud. Pendidik. Bhs. dan Sastra Jawa, Vol. 05, No. 02, Pp. 35-36, 2014, [Online]. Available: Http://Ejournal.Umpwr.Ac.Id/Index.Php/Aditya/Article/View/1579.

[2] V. R. Sagita and T. Setiawan, "Bentuk dan Jenis Tindak Tutur Ilokusi Ridwan Kamil Dalam Talkshow Insight Di Cnn Indonesia," J. Lensa Kaji. Kebahasaan, Kesusastraan, Dan Budaya, Vol. 9, No. 2, Pp. 1-14, 2019, [Online]. Available: Https://Digilibadmin.Unismuh.Ac.Id/Upload/12509-Full_Text.Pdf.

[3] G. Yule, Pragmatik (Edisi Terjemahan Oleh Indah Fajar Wahyuni Dan Rombe Mustajab). Yogyakarta: Pustaka Pelajar, 2006.

[4] S. F. Altikriti, "Speech Act Analysis to Short Stories," J. Lang. Teach. Res., Vol. 2, No. 6, Pp. 1374-1384, 2011, Doi: 10.4304/Jltr.2.6.1374-1384.

[5] S. Faroh and A. P. Y. Utomo, "Tindak Tutur Ilokusi dalam Vlog Q\&A Sesi 3 pada Kanal Youtube Sherly Annavita Rahmi," Undas J. Has. Penelit. Bhs. Dan Sastra, Vol. 16, No. 2, Pp. 311-326, 2020, Doi: Https://Doi.Org/10.26499/Und.V16i2.2793.

[6] I. M. P. Adhiguna, I. N. A. Susrawan, and D. G. B. Erawan, "Analisis Tindak Tutur Lokusi, Ilokusi, dan Perlokusi dalam Proses Pembelajaran Bahasa Indonesia di Kelas Xi Mipa 7 Sma N 7 Denpasar Tahun Pelajaran 2018/2019," J. Bakti Sar., Vol. 08, No. 02, Pp. 204-211, 2019, [Online]. Available: Https://EJournal.Unmas.Ac.Id/Index.Php/Baktisaraswati/Article/View/620.

[7] I. D. P. Wijana, Dasar-Dasar Pragmatik. Yogyakarta: Andi Offset, 1996.

[8] W. T. Marwuni and A. P. Y. Utomo, "Analisis Tindak Tutur Ilokusi di Cuitan Akun Twitter@Sudjiwotedjo Pada Bulan Februari 2020," Kadera Bhs., Vol. 12, No. 1, Pp. 2333, 2020, [Online]. Available: Https://Kaderabahasa.Kemdikbud.Go.Id/Jurnal/Index.Php/Kaderabahasa/Article/View/12 2.

[9] Adriesty Salma Lailika and A. Purwo Yudi Utomo, "Analisis Tindak Tutur Representatif dalam Podcast Deddy Corbuzier Dengan Nadiem Makarim-Kuliah Tidak Penting?," Bahtera Indones. J. Penelit. Bhs. Dan Sastra Indones., Vol. 5, No. 2, Pp. 97-109, 2020, Doi: 10.31943/Bi.V5i2.70.

[10] N. Widyawati And A. P. Y. Utomo, "Tindak Tutur Ilokusi dalam Video Podcast Deddy Corbuzier dan Najwa Shihab pada Media Sosial Youtube," J. Ilmiahtelaah, Vol. 5, No. 2, Pp. 18-27, 2020, Doi: Https://Doi.Org/10.31764/Telaah.Vxiy.2377 //Doi.Org/10.31764/Telaah.Vxiy.23777. 
[11] H. F. Rukmana, Suryadi, And I. Diani, "Tindak Tutur Guru dalam Pembelajaran Bahasa Indonesia di Kelas VII Tunagrahita SMP lb Dharma Wanita Persatuan Provinsi Bengkulu," J. Korpus, Vol. 1, No. 1, Pp. 1-10, 2017, [Online]. Available: Https://Ejournal.Unib.Ac.Id/Index.Php/Korpus/Article/Download/4122/2292.

[12] I. S. Muwalidah, "Analisis Tindak Tutur Ilokusi dalam Wacana Pembaca Menulis pada Surat Kabar Jawa Pos Edisi September 2014," Universitas Muhammadiyah Surakarta, 2015.

[13] Y. S. Hartati, "Tindak Tutur Asertif Dalam Gelar Wicara Mata Najwa di Metro Tv," J. Kata, Vol. 2, No. 2, P. 296, 2018, Doi: 10.22216/Jk.V2i2.3151.

[14] I. Sourou Koutchadé, "Analysing Speech Acts In Buhari's Address At The 71st Session Of The Un General Assembly," Int. J. Appl. Linguist. English Lit., Vol. 6, No. 3, P. 226, 2017, Doi: 10.7575/Aiac.Ijalel.V.6n.3p.226.

[15] S. T. Wahyuni, I. I. Ratnawati, and Retnowaty, "Tindak Tutur Ilokusi pada Caption Akun Islami Di Instagram," Basa Tak. Univ. Balikpapan, Vol. 1, No. 2, Pp. 11-18, 2018, [Online]. Available: Https://Jurnal.Pbsi.UnibaBpn.Ac.Id/Index.Php/Basataka/Article/View/25.

[16] Dirmawati, A. Tolla, and Ramly, "Tindak Tutur Ilokusi dalam Proses Perkuliahan Mahasiswa Program Studi Sastra Indonesia Fakultas Bahasa dan Sastra Universitas Negeri Makassar," 2018, [Online]. Available: Http://Eprints.Unm.Ac.Id/Id/Eprint/10845.

[17] M. Helga Et Al., "Analisis Tindak Tutur Lokusi, Ilokusi, Perlokusi pada Dialog Film $5 \mathrm{~cm}$ Karya Rizal Mantovani (Sebuah Tinjauan Pragmatik)," Jipbsi J. Ilm. Pendidik. Bhs. Dan Sastra Indones., Vol. 1, No. 1, Pp. 98-105, 2020, [Online]. Available: Https://EJournal.Unmas.Ac.Id/Index.Php/Jipbsi/Article/View/1604.

[18] R. K. Pratama And A. P. Y. Utomo, "Analisis Tindak Tutur Ekspresif dalam Wacana Stand Up Comedy Indonesia Sesi 3 Babe Cabita Di Kompas Tv," Caraka, Vol. 6, No. 2, P. 90, 2020, Doi: 10.30738/.V6i2.7841.

[19] S. Asia, "Analisis Tindak Tutur Ilokusi Perempuan dalam Pusat Perbelanjaan Mall Panakukang Makassar," Universitas Muhammadiyah Makassar, 2020. 